P-ISSN 2580 - 7781

E-ISSN 2615 - 3238

\title{
PENGARUH PENAMBAHAN BIOAKTIVATOR EM-4 TERHADAP PRODUKSI BIOGAS DARI LIMBAH CAIR INDUSTRI TAHU
}

\section{THE EFFECT OF ADDITIONAL EM-4 BIOACTIVATOR ON BIOGAS PRODUCTION FROM TOFU INDUSTRIAL LIQUID WASTE}

\author{
Jamiluddin Ahmad Muzakki \\ Teknik Mesin, Fakultas Teknik, Universitas Panca Marga Probolinggo \\ ${ }^{1}$ Email: ajamiluddin@gmail.com
}

\begin{abstract}
ABSTRAK
Limbah industri tahu pada umumnya dibagi menjadi dua bentuk limbah, yaitu limbah padat dan limbah cair. Limbah cair industri tahu mengandung bahan organik yang dapat diuraikan secara anaerob menjadi gas metana $\left(\mathrm{CH}_{4}\right)$, gas-gas lain, dan air yang biasa disebut biogas. Salah satu biokatalis yang berpotensi sebagai sumber mikroorganisme dalam pembuatan biogas adalah Effective Microorganisms 4 (EM-4). Penelitian ini dilakukan dengan menambahkan EM-4 dengan konsentrasi 0,5\%; 1\%; dan tanpa EM-4 ke dalam 15 liter limbah cair tahu di dalam digester untuk dilakukan fermentasi selama 7 hari. Pengamatan tekanan pada manometer dilihat dari beda ketinggian cairan manometer $\mathrm{U}$ dan proses pembakaran dilakukan pada hari ke-7 (tekanan konstan). Tekanan maksimum biogas selama 7 hari yakni pada EM4 $1 \%$ sebesar 927,864 kg/m.s $\mathrm{s}^{2}$ menghasilkan api berwarna biru, bau tidak sedap, tidak menimbulkan asap dengan tinggi api 12,602 mm. Sehingga dapat disimpulkan bahwa semakin besar konsentrasi EM-4 yang digunakan, akan menghasilkan tekanan biogas dan api yang semakin besar.
\end{abstract}

Kata kunci: Limbah industri tahu, Effective microorganisms 4, Biogas

\section{ABSTRACT}

Tofu industrial waste is generally divided into two forms of waste, namely solid waste and liquid waste. The liquid waste of the tofu industry contains organic material that can be decomposed anaerobically into methane gas $\left(\mathrm{CH}_{4}\right)$, other gases, and water which is commonly called biogas. One of the potential biocatalysts as a source of microorganisms in biogas production is Effective Microorganisms 4 (EM-4). This research was conducted by adding EM-4 with a concentration of 0.5\%; 1\%; and without EM-4 into 15 liters of tofu liquid waste in the digester for fermentation for 7 days. Observation of the pressure on the manometer seen from the difference in the height of the liquid manometer $U$ and the combustion process was carried out on the 7th day (constant pressure). The maximum pressure of biogas for 7 days at 1\% EM4 of 927,864 kg/m.s produces a blue flame, has an unpleasant odor, does not cause smoke with a fire height of 12,602 $\mathrm{mm}$. So it can be concluded that the greater concentration of EM-4 used, the greater the pressure of biogas and fire.

Keywords: Tofu industrial waste, Effective Microorganisms 4, and Biogas. 
P-ISSN 2580 - 7781

E-ISSN 2615 - 3238

\section{PENDAHULUAN}

Jumlah industri tahu di Indonesia mencapai kurang lebih 84.000 unit usaha dengan kapasitas produksi lebih dari 2,56 juta ton per tahun dengan produksi limbah cair sebanyak 20 juta meter $^{3}$ per tahun (Setiawan \& Rusdjijati, 2014). Limbah cair berasal dari air cucian, rendaman, dan juga perebusan kedelai yang memiliki bau yang tidak sedap, mengandung gas oksigen $\left(\mathrm{O}_{2}\right)$, amonia $\left(\mathrm{NH}_{3}\right)$, karbondioksida $\left(\mathrm{CO}_{2}\right)$ dan metana $\left(\mathrm{CH}_{4}\right)$ (Sally, Budianto, Hakim, \& Kiyat, 2019). Limbah cair tahu juga memiliki kandungan Biological Oxygen Demand (BOD) dan Chemical Oxygen Demand (COD) cukup tinggi yang menyebabkan air sungai menjadi tercemar dan mengganggu warga sekitar (Subekti, 2011). Senyawa organik yang terkandung dalam limbah cair industri tahu dapat diuraikan baik secara aerob maupun anaerob yang akan menghasilkan gas metana $\left(\mathrm{CH}_{4}\right)$, karbondioksida $\left(\mathrm{CO}_{2}\right)$, gas-gas lain, dan air. Gas ini dikenal dengan gas rawa atau biogas (Setiawan \& Rusdjijati, 2014).

Prinsip kimia yang berkaitan dengan pembentukan biogas umumnya menggunakan fermentasi anaerob (tidak menggunakan udara) dari semua karbohidrat, lemak, dan protein oleh bakteri metanogen. Salah satu biokatalis yang berpotensi sebagai sumber mikroorganisme dalam pembuatan biogas adalah Effective Microorganisms 4 (EM-4). Penambahan EM-4 bertujuan untuk mempercepat. Selain itu, penambahan EM-4 secara teknis mudah didapatkan di pasaran dan harganya relatif murah (Paturohman, 2009). Keunggulan dari biogas antara lain tidak berbau, mudah terbakar, menghasilkan nyala api berwarna biru tanpa asap sehingga tidak berpotensi menimbulkan polusi (Akwaka, Kukwa \& Mwekayen 2014). Oleh karenanya dilakukan penelitian produksi biogas dari limbah cair industri tahu dengan bioaktivator EM-4 untuk mengetahui pengaruh penambahan bioaktivator terhadap kualitas biogas.

\section{METODE PENELITIAN}

\section{Bahan}

1. Limbah cair tahu

2. Bioaktivator Effective Microorganisms 4 (EM-4) 
P-ISSN 2580 - 7781

E-ISSN 2615 - 3238

\section{Rangkaian Alat}

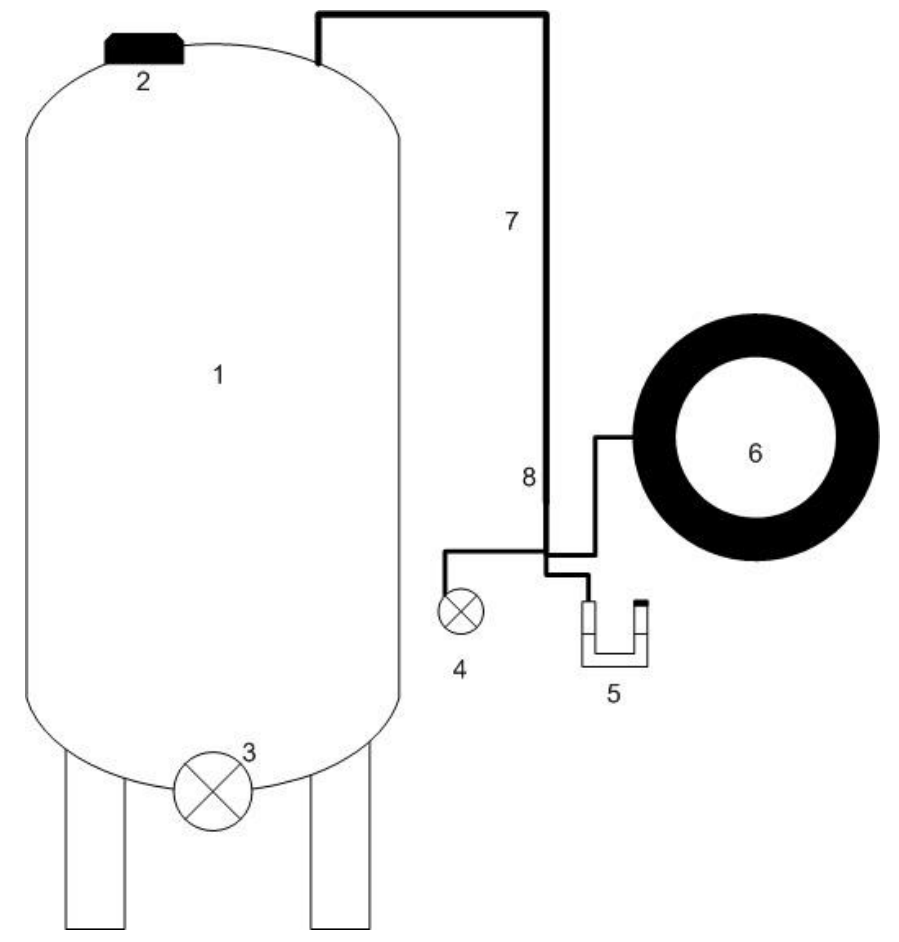

Gambar 1. Rancangan Alat

Keterangan Gambar :

1. Tabung fermentasi modifikasi

2. Tutup tabung fermentasi

3. Kran pembuangan limbah

4. Kran besi kecil ukuran 1/4

5. Manometer U tertutup

6. Ban dalam penampung gas

7. Selang

8. Y valve

\section{Variabel}

Adapun variabel yang digunakan dalam penelitian ini yaitu, (a) Variabel Terikat yang digunakan yakni limbah cair tahu 15 liter, lama waktu fermentasi 7 hari; (b) Variabel Bebas yang digunakan yakni Bioaktivator Effective Microorganisms 4 (EM-4) $(0,5 \% ; 1 \%$; dan tanpa EM4). 
P-ISSN 2580 - 7781

E-ISSN 2615 - 3238

\section{METODE PENELITIAN}

1. Limbah cair tahu 15 liter dan Bioaktivator Effective Microorganisms 4 (sesuai variable) dimasukkan kedalam tabung fermentasi (tabung minyak tanah yang dimodifikasi).

2. Tutup rapat tabung fermentasi dan simpan di tempat gelap selama 7 hari.

3. Setiap hari dilakukan pengamatan tekanan pada manometer dan dilakukan pengadukan pada tabung agar fermentasi lebih maksimal.

4. Setelah 7 hari, dilakukan analisa terhadap karakteristik api yang dihasilkan.

\section{HASIL PENELITIAN DAN PEMBAHASAN}

Berdasarkan hasil penelitian, diperoleh data perbedaan ketinggian cairan di dalam manometer U sebagai berikut:

Tabel 1. Perbedaan Ketinggian Cairan Manometer U

\begin{tabular}{cccc}
\hline \multicolumn{4}{c}{ Beda Ketinggian Manometer $(\mathrm{cm})$} \\
\hline Hari ke- & \multicolumn{2}{c}{ Konsentrasi EM4 } & Tanpa EM4 \\
\cline { 2 - 4 } & $0,5 \%$ & $1 \%$ & - \\
\hline 1 & 4 & 5 & - \\
\hline 3 & 4 & 6 & - \\
\hline 4 & 5 & 6 & 0.7 \\
\hline 5 & 5 & 10 & 1 \\
\hline 6 & 6 & 11 & 1 \\
\hline 7 & 6 & 12 & \\
\hline
\end{tabular}

Berdasarkan data tersebut, semakin lama waktu fermentasi dengan konsentrasi EM4 yang sama diperoleh beda ketinggian cairan dalam manometer juga semakin besar. Pada konsentrasi EM4 0,5\% diperoleh beda ketinggian konstan pada hari ke 5 sampai hari ke 7 yakni $6 \mathrm{~cm}$. Sedangkan pada konsentrasi EM4 1\% diperoleh beda ketinggian konstan pada hari ke 6 sampai hari ke 7 yakni 
P-ISSN 2580 - 7781

E-ISSN 2615 - 3238

$2 \mathrm{~cm}$. Pada tanpa penambahan EM4 diperoleh beda ketinggian pada hari ke-7 sebesar $1 \mathrm{~cm}$. Dalam hal ini, penambahan konsentrasi EM4 1\% memiliki perbedaan ketinggian cairan manometer lebih besar dibandingkan dengan penambahan EM4 0,5\% dan tanpa EM4. Semakin besar perbedaan ketinggian cairan dalam manometer akan menghasilkan tekanan yang semakin besar pula.

Diperoleh data tekanan biogas yang dihasilkan menggunakan perhitungan persamaan hidrostatis disajikan dalam Tabel 2 sebagai berikut :

Tabel 2. Tekanan Biogas dari Limbah Cair Tahu

\begin{tabular}{cccc}
\hline \multicolumn{4}{c}{ Tekanan $\left(\mathrm{kg} / \mathrm{m} . \mathrm{s}^{\wedge} 2\right)$ atau $(\mathrm{Pa})$} \\
\cline { 2 - 3 } Hari ke- & \multicolumn{2}{c}{ Konsentrasi EM4 } & Tanpa EM4 \\
\cline { 2 - 3 } & $0,5 \%$ & $1 \%$ & \\
\hline 1 & 309.288 & 386.61 & - \\
\hline 2 & 309.288 & 463.932 & - \\
\hline 3 & 386.61 & 463.932 & - \\
\hline 4 & 386.61 & 773.22 & - \\
\hline 5 & 463.932 & 850.542 & 54.125 \\
\hline 6 & 463.932 & 927.864 & 77.322 \\
\hline 7 & 463.932 & 927.864 & 77.322 \\
\hline
\end{tabular}


P-ISSN 2580 - 7781

E-ISSN 2615 - 3238

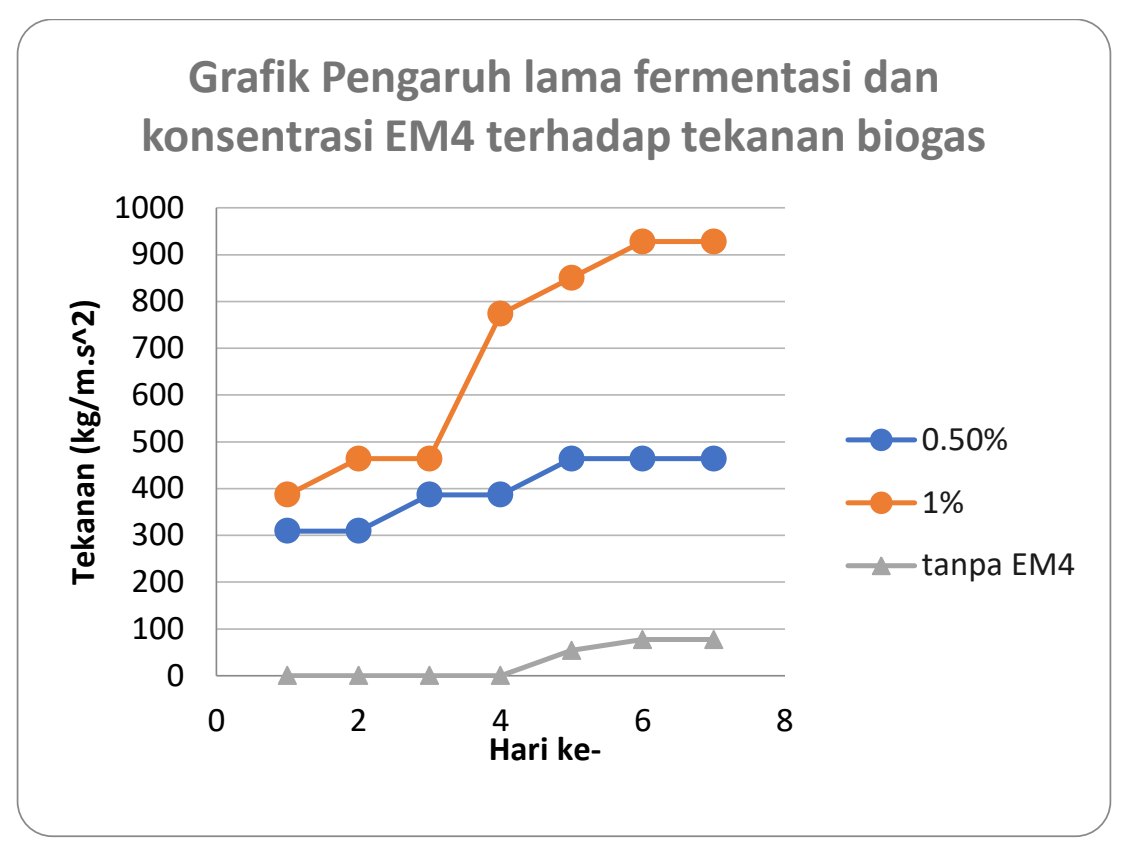

Gambar 2. Grafik Pengaruh Lama Fermentasi dan Konsentrasi EM4 Terhadap Tekanan Biogas

Berdasarkan data tersebut, semakin lama waktu fermentasi dalam konsentrasi EM4 yang sama diperoleh data tekanan biogas yang dihasilkan semakin besar. Hal tersebut, mengidentifikasi bahwasanya biogas yang dihasilkan juga semakin banyak seiring dengan lamanya waktu fermentasi. Pada konsentrasi EM4 0,5\% diperoleh tekanan tertinggi dan konstan pada hari ke-7 yakni 463,932 $\mathrm{kg} / \mathrm{m} . \mathrm{s}^{2}$. Sedangkan konsentrasi EM4 1\% diperoleh tekanan tertinggi dan konstan pada hari ke-7 yakni $927,864 \mathrm{~kg} / \mathrm{m}^{2} \mathrm{~s}^{2}$. Pada variabel tanpa penambahan EM4 diperoleh tekanan tertinggi pada hari ke-7 sebesar 77,322 kg/m.s .

Selain pengaruh lamanya waktu fermentasi, pembentukan biogas juga dipengaruhi oleh konsentrasi EM4. Menurut Romzi (2019) penambahan EM-4 mempunyai pengaruh terhadap hasil biogas yang dihasilkan. Semakin banyak EM4 yang digunakan, tekanan biogas yang dihasilkan juga semakin besar. Hal ini sesuai dengan penelitian tersebut. Berdasarkan penelitian, penambahan EM4 1\% menghasilkan tekanan biogas yang lebih besar dibandingkan dengan penambahan EM4 0,5\% dan tanpa EM4. Selain itu, pada penambahan EM4 1\% terjadi proses fermentasi yang cukup cepat. Hal ini dibuktikan pada hari ke-1 menghasilkan tekanan yang cukup besar dibandingkan dengan penambahan EM4 0,5\% dan tanpa EM4. Hal tersebut menunjukkan bahwasanya penambahan starter EM4 


\section{P-ISSN 2580 - 7781}

E-ISSN 2615 - 3238

dapat mempercepat pembentukan biogas dari limbah cair tahu dikarenakan EM4 memiliki sekitar 80 genus mikroorganisme fermentasi yang bermanfaat terutama diantaranya bakteri fotosietik, Lactobacillus sp., Streptomyces sp., Actinomycetes $s p$. dan ragi yang dapat melepaskan hasil-hasil fermentasi berupa alcohol, gula, dan lain-lain. Sehingga dapat mempercepat pembentukan gas metana dari limbah cair tahu.

\section{Hasil Pengujian Nyala Api Biogas}

Pada hari ke-7, gas yang dihasilkan ditampung pada ban sepeda. Lalu dilakukan pembakaran biogas saat tekanan manometer bernilai konstan. Dalam penelitian ini, pembakaran biogas dilakukan dengan menyulutkan sumber api pada ujung selang. Adapun hasil dari pembakaran biogas seperti pada Gambar 3 dan Gambar 4 berikut.

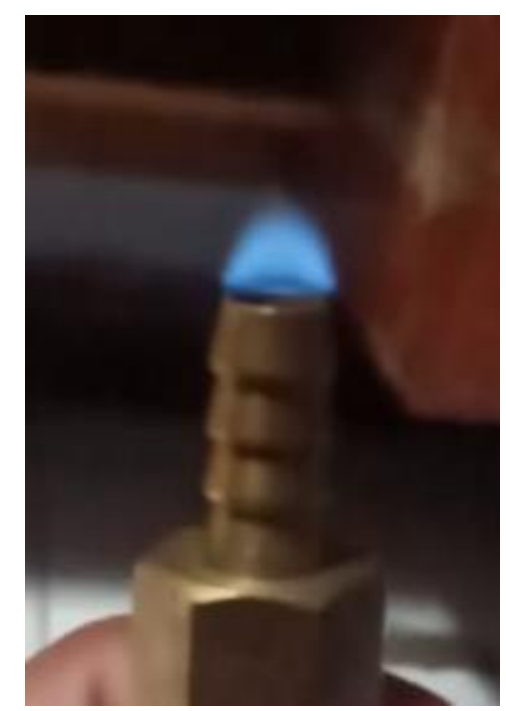

Gambar 3. Api Pembakaran Biogas EM40,5\%

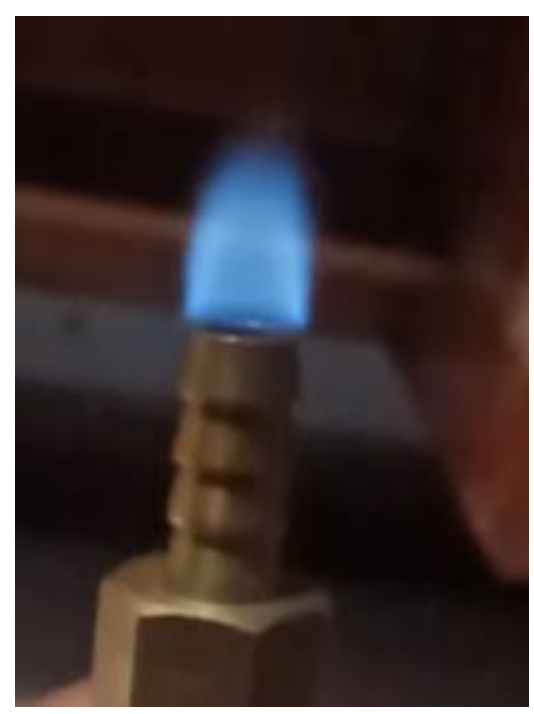

Gambar 4. Api Pembakaran Biogas EM4 1\%

Nyala api merupakan salah satu indikator berhasil atau tidaknya proses fermentasi pada pembuatan biogas tersebut. Menurut (Hidayat \& Utomo 2012), api pembakaran biogas dari limbah cair tahu berwarna biru yang menunjukkan bahwasanya proses pembakaran berlangsung cukup sempurna. Sehingga biogas dapat digunakan dalam kehidupan sehari-hari. Apabila gas metana yang terkandung masih rendah, maka biogas tidak bisa terbakar. 
P-ISSN 2580 - 7781

E-ISSN 2615 - 3238

Berdasarkan percobaan tersebut, pada penambahan EM4 0,5\% warna api dari pembakaran biogas berwarna biru, sedikit berbau tidak sedap dan tidak menghasilkan asap namun api yang dihasilkan masih kecil. Sedangkan pada penambahan EM4 1\% warna api dari pembakaran biogas berwarna biru, sedikit berbau tidak sedap dan tidak menghasilkan asap dan api yang dihasilkan cukup besar. Hal ini sesuai dengan penelitian Hidayat dan Utomo (2012) yang menunjukkan bahwasanya hasil pembentukan gas metana $\left(\mathrm{CH}_{4}\right)$ memiliki kandungan gas diatas $40 \%$. Sedangkan pada variabel tanpa penambahan EM4 tidak terdapat nyala api dikarenakan tekanan gas yang dihasilkan terlalu kecil. Sehingga kandungan metana di dalam gas juga kecil.

Menurut penelitian Ihsan, Bahri, dan Musafira (2013) jika gas yang dihasilkan dari proses fermentasi anaerob dapat terbakar maka kemungkinan mengandung $45 \%$ gas metana. Pada umumnya pembakaran gas metana akan menghasilkan nyala api berwarna biru dan tidak mudah padam. Apabila nyala api berwarna sedikit oranye menandakan bahwasanya biogas masih mengandung air dengan presentase yang kecil (Elfiano, Fadhilah, \& Masdar, 2019).

Adapun jenis api yang dihasilkan dalam penelitian ini merupakan api premix. Hal tersebut dikarenakan nyala api terjadi ketika bahan bakar dan udara tercampur sempurna terlebih dahulu kemudian terjadi reaksi pembakaran yang dapat juga didefinisikan sebagai keadaan kesetimbangan dari temperatur nyala adiabatik dan kecepatan nyala. Nyala api tersebut memiliki karakteristik dengan komposisi warna kebiruan.

Api yang dihasilkan dilakukan analisa lanjutan terkait kualitas api yakni tinggi api pembakaran menggunakan aplikasi ImageJ. Ujung burner api digunakan sebagai acuan untuk menentukan tinggi api. Dilakukan pengukuran terlebih dahulu pada ujung burner, didapat tinggi burner sebesar $15 \mathrm{~mm}$. Pada menu straight, tarik garis dari ujung burner ke ujung yang lain. Kemudian menuju menu analyze dan pilih set scale untuk menentukan tinggi burner. Ubah unit of length menjadi satuan "mm" pada kolom known distance, isi sesuai tinggi burner yang telah diukur lalu tekan "ok". Pada menu straight tarik garis dari ujung api sampai 
P-ISSN 2580 - 7781

E-ISSN 2615 - 3238

ujung burner. Kemudian pada menu analyze pilih measure, tinggi api dapat diketahui pada tabel Length.

Berdasarkan hasil analisa, diperoleh hasil seperti berikut:

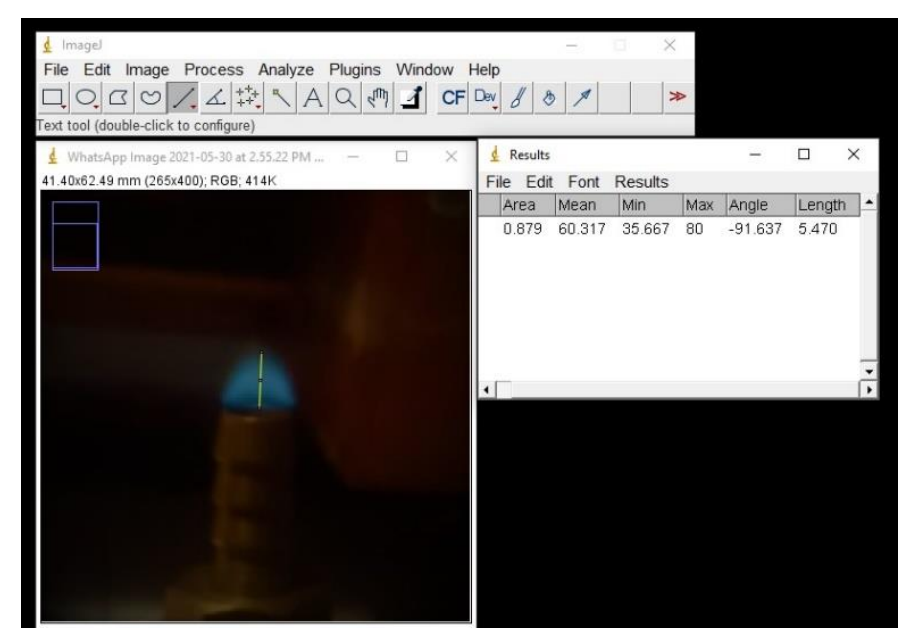

Gambar 5. Karakteristik Tinggi Api EM4 0,5\%

Berdasarkan aplikasi ImageJ, pada penambahan EM4 0,5\% diperoleh tinggi api sebesar 5,470 $\mathrm{mm}$ seperti pada Gambar 5. Hal tersebut menandakan bahwasanya api pembakaran masih kecil sehingga tidak dapat digunakan untuk keperluan yang membutuhkan api besar.

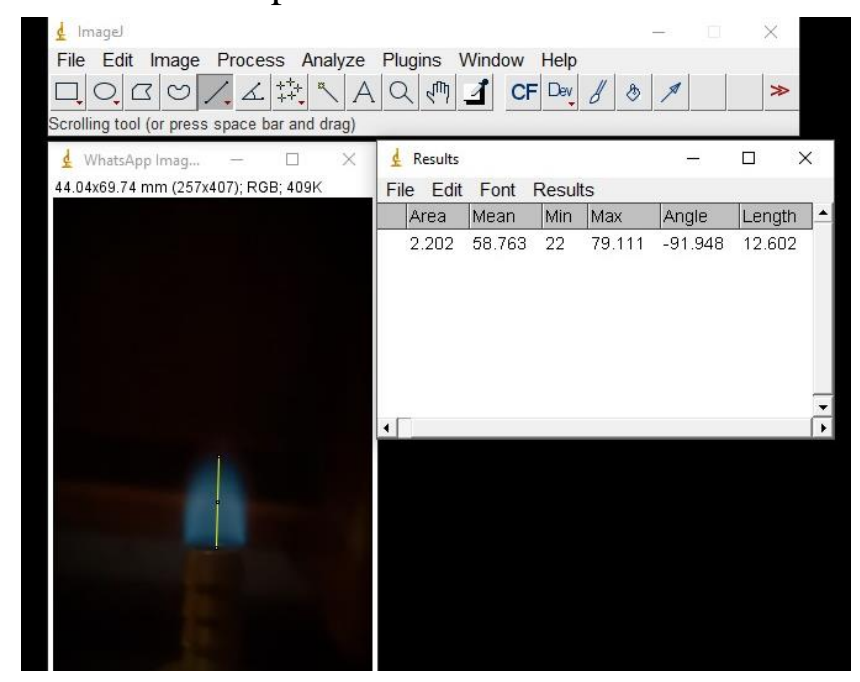

Gambar 6. Karakteristik Tinggi Api EM4 1\%

Berdasarkan aplikasi ImageJ, pada penambahan EM4 1\% diperoleh tinggi api sebesar 12,602 mm seperti pada Gambar 6. Hal tersebut menandakan bahwasanya api pembakaran tersebut lebih besar dibandingan dengan api 
P-ISSN 2580 - 7781

E-ISSN 2615 - 3238

pembakaran pada penambahan EM4 0,5\%. Berikut grafik hubungan konsentrasi EM4 dengan tinggi api seperti pada Gambar 7.

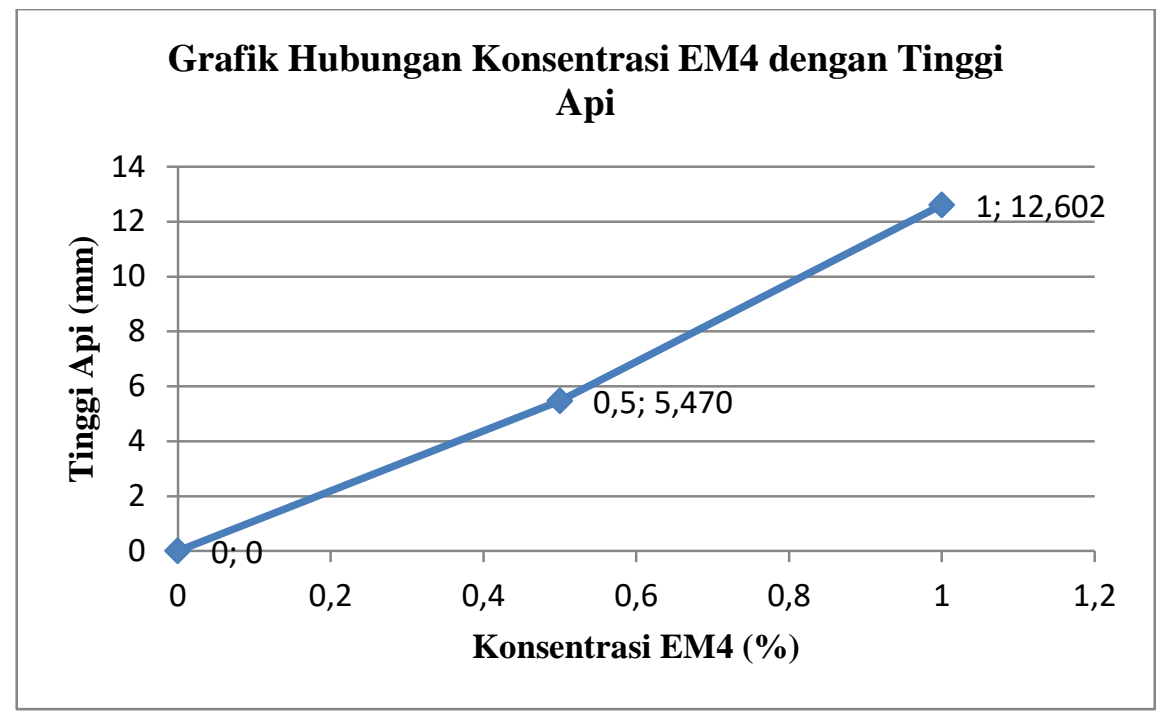

Gambar 7. Grafik Hubungan Tinggi Api dengan Konsentrasi EM4

Berdasarkan Gambar 7, diperoleh bahwasanya penambahan EM4 berpengaruh terhadap kualitas api yang dihasilkan. Semakin besar EM4 yang ditambahkan, maka tinggi api yang dihasilkan juga semakin besar.

\section{KESIMPULAN}

Penambahan Bioaktivator EM4 dapat mempercepat pembentukan biogas, semakin besar konsentrasi EM-4 yang digunakan, akan menghasilkan tekanan biogas dan api yang semakin besar. Karakteristik api premix yang dihasilkan biogas limbah cair tahu berwarna biru, berbau tidak sedap, dan tidak berasap. Agar biogas yang dihasilkan lebih maksimal, perlu dilakukan penambahan waktu fermentasi kurang lebih selama 30 hari. Perlu dilakukan penelitian lanjutan dengan menggunakan jenis starter yang berbeda, contohnya dengan kotoran sapi atau bahan organik lainnya.

\section{DAFTAR PUSTAKA}

Akwaka, J. C., Kukwa, D. T., \& Mwekaven, S. S. 2014. Preliminary Study On Co-Digestion Of Cow Manure With Pretreated Sawdust For Production Of Biogas And Biofertilizer. International Journal of Science and Technology, 3(4), 222-228.

Elfiano, E., Fadhilah, M. C., \& Masdar, M. S. 2019. Sistem Biogas Sebagai Energi Terbarukan Skala Rumah Tangga Dengan Memanfaatkan Limbah 
P-ISSN 2580 - 7781

E-ISSN 2615 - 3238

Kotoran Burung Puyuh. Journal of Renewable Energy \& Mechanics (REM), 2(02), 92-98. https://doi.org/10.25299/rem.2019.vol2.no02.3650

Hidayat, M. R., \& Utomo, H. P. 2012. Produksi Biogas dari Limbah Cair Industri Tahu dengan Biokatalis Effective Microorganisms 4 (EM4). BIOPROPAL INDUSTRI, 3(1), 6.

Ihsan, A., Bahri, S., \& Musafira. 2013. Produksi Biogas Menggunakan Cairan Isi Rumen Sapi Dengan Limbah Cair Tempe. Online Jurnal of Natural Science, 2(2), 27-35.

Paturohman, M. 2009. Potensi Sampah Buah-buahan sebagai Bahan Bakar Alternatif (Biogas) Melalui Fermentasi Aerobik dan Anaerobik.

Romzi, Z. A. 2019. Analisa Pengaruh Penambahan Bioaktiva EM4 pada Bahan Limbah Tahu Cair Terhadap Hasil Biogas. Skripsi Teknik Mesin. Universitas Nusantara PGRI Kediri.

Sally, S., Budianto, Y. P., Hakim, M. W. K., \& Kiyat, W. El. 2019. Potensi Pemanfaatan Limbah Cair Tahu Menjadi Biogas Untuk Skala Industri Rumah Tangga Di Provinsi Banten. Agrointek, 13(1), 43. https://doi.org/10.21107/agrointek.v13i1.4715

Setiawan, A. dan, \& Rusdjijati, R. 2014. Peningkatan Kualitas Biogas Limbah Cair Tahu Dengan Metode Taguchi. Prosiding SNATIF Journals, 1(1), 35-40.

Subekti, S. 2011. Pengolahan Limbah Cair Tahu Menjadi Biogas Sebagai Bahan Bakar Alternatif. Sains Dan Teknologi, (1), 1-6. 